\title{
Relasi Ruang Publik Dan Pers Menurut Habermas
}

\author{
Yadi Supriadi ${ }^{1}$ \\ Fakultas Ilmu Komunikasi Universitas Islam Bandung
}

\begin{abstract}
The long history of journalism is in accordance with the development of the concept of public sphere. This study seeks to examine the origin of public journalism by using the concept of Jurgen Habermas about public sphere ontology, history of the press, and the relation of public sphere and the press. This research employs a literature study related to journalism and public sphere. Results show that the public concept attached to the public sphere has different definition historically. Research concludes the most suitable concept of public sphere for Indonesia nowadays. The public sphere of Habermas has two forms; political public sphere and literature public sphere. Through the two concepts of public sphere of Habermas, researcher explains the relations between public sphere and the press and the emergence public journalism concept.
\end{abstract}

Keywords: history of journalism, information, public journalism, public sphere

\begin{abstract}
Abstrak
Sejarah panjang jurnalisme sejalan dengan perkembangan konsep ruang publik. Penelitian ini berupaya mengkaji asal mula jurnalisme publik dengan menggunakan pandangan Jurgen Habermas mengenai ontologi ruang publik, sejarah pers, dan hubungan ruang publik dengan pers. Penelitian ini dilakukan dengan menggunakan studi kepustakaan yang berkaitan dengan jurnalisme dan ruang publik. Hasil penelitian menunjukkan, konsep publik yang melekat pada ruang publik memiliki pengertian berbeda dalam sejarah. Pada akhirnya ditemukannya konsep ruang publik yang sejalan dengan pandangan kita saat ini. Ruang publik dalam pandangan Habermas memiliki dua bentuk; ruang publik politik dan ruang publik sastra. Melalui dua konsep ruang publik, peneliti memaparkan keterkaitan ruang publik dan pers dalam pandangan
\end{abstract}

\footnotetext{
${ }^{1}$ Korespondensi Penulis:

Yadi Supriadi, Fakultas IImu Komunikasi Universitas Islam Bandung, Jl. Tamansari No. 1 Bandung, Jawa Barat, Indonesia

supriadias71@gmail.com
} 
Habermas hingga munculnya konsep jurnalisme publik.

Kata Kunci: informasi, jurnalisme publik, ruang publik, sejarah jurnalisme

\section{Pendahuluan}

Istilah jurnalistik dalam bahasa Indonesia mengacu pada kata de jour dalam bahasa Perancis yang berarti kegiatan pencatatan sehari-hari. Pencatatan tersebut berkaitan dengan informasi-informasi yang berhubungan dengan kepentingan publik. Sementara itu menurut Junaedhi (1991:113), istilah jurnalistik dalam bahasa Indonesia berasal dari bahasa Belanda; journalistik dan bahasa Inggris journalism.

Adapun istilah lain yang sering dikaitkan dengan kegiatan jurnalistik adalah Acta Diurna - sebuah papan pengumuman yang berisikan tulisan-tulisan dari pemerintahan Romawi (Cangara, 1998:21). Melalui pemasangan berita pada Acta Diurna tersebut, rakyat Romawi dapat membaca atau melukiskan berita guna disebarluaskan untuk kepentingan publik. Pelukisan berita itu bisa dilakukan secara lisan maupun tulisan. Orang-orang yang membaca langsung Acta Diurna setara dengan reporter pada kegiatan jurnalistik masa kini. Sunarjo (1991:22) melukiskan bahwa seorang ahli sejarah Romawi yang bernama Suetonius mengatakan, pada saat penobatan Julius Caesar menjadi konsul pada tahun 59 SM ia memerintahkan agar Acta Diurna dipasang di stadion Romawi atau Forum Romanum untuk kepentingan informasi masyarakat.

Memasuki era industrialisasi, terutama dengan ditemukannya mesin cetak oleh Guntenberg, kegiatan pencatatan berlangsung dalam skala lebih besar dan cepat. Buku-buku, jurnal, serta injil dicetak di Eropa. Jurnalistik kemudian memiliki wajah baru. Ia tidak hanya kegiatan yang diperlukan bagi publik, tetapi kepentingan bisnis juga muncul seiring dengan teknologi yang berkembang. Kegiatan jurnalistik kemudian dikenal dengan nama pers. Nama ini sebenarnya merujuk pada sebuah lembaga yang memiliki kekuatan untuk mengelola informasi dan teknologi dengan modal yang kuat. Kegiatan jurnalistik yang dikelola pers bukan hanya sebagai kegiatan penyampaian informasi semata, tetapi dilengkapi dengan unsur bisnis dan persaingan antar lembaga. Oleh karena itu, membludaknya berita dan berbagi informasi menandai zaman baru di era teknologi (pos, telegraf, telepon, radio, televisi, maupun internet) saat ini.

Keberadaan pers menjadi ruang bagi publik dalam memperoleh maupun menyampaikan informasi yang penting bagi masyarakat. Dasar ontologis mengenai masyarakat pada hakikatnya dapat menjadi titik tolak dalam memahami konsep civil society sebagaimana yang sekarang sedang berkembang. Dalam wacana dewasa ini menurut Haryatmoko (2003:211), civil society mengandung dua makna: pertama, pengertian civil society yang dikaitkan dengan institusi-institusi atau organisasi; kedua, pengertian yang lebih merupakan seperangkat konsep yang setara dengan konsep kewarganegaraan di dalam suatu tatanan demokrasi. Pengertian kedua ini berkaitan dengan konsep masyarakat tentang kebebasan berpendapat dan berkumpul, hak untuk 
memilih dan dipilih dalam jabatan-jabatan publik, kebebasan pers, hak berkesenian dan berekspresi, dan sebagainya.

Dua pengertian di atas kemudian mendorong adanya suatu aturan yang dapat mengontrol seluruh anggota masyarakat dalam civil society. Pada prinsipnya, civil society menuntut adanya kesadaran masyarakat akan kehidupan bersama dan setara, bukan kehidupan yang berjalan dengan prinsip dominasi. Adanya negara, agama, kelompok sosial, harus dilandasi dengan prinsip tujuan hidup teratur dan saling menghormati. Dalam konteks ini, kekuasaan dengan sikap ingin mendominasi, maupun kepentingan pribadi harus dihindari. Peranan pers dalam civil society menjadi pengawas bagi terlaksanya kehidupan masyarakat yang baik sesuai dengan harapanharapan masyarakat.

Pers sendiri sebagai lembaga publik tentu harus berperan aktif dalam membangun ruang publik yang sehat. Saluran-saluran aspirasi maupun politik mesti dibuka secara lebar sehingga ruang publik benar-benar menjadi arena dimana setiap gagasan masyarakat muncul, saling bertemu dan dialogis. Partisipasi masyarakat luas dalam skala besar menjadi kunci utama. Partisipasi itu sendiri menurut Jones (2009:30) adalah tersedianya akses, komunitas, dan kebebasan di dalam informasi. Lebih jauh lagi ia menegaskan, penggunaan internet untuk pengembangan dialog masyarakat dapat mendorong pengawasan pada kebijakan publik. Gerakan masyarakat ini dapat menjadi kekuatan kolektif dalam ruang publik.

Relasi antara ruang publik dan pers menjadi ini juga menjadi perhatian Jürgen Habermas. Dalam karyanya yang berjudul The Structural Transformation of the Public Sphere (1989), Habermas menganalisis bagaimana perkembangan pers terjadi seiring dengan perkembangan ruang publik. Karya ini pertama kali terbit dalam bahasa Jerman dengan judul Strukturwandel der Offentlichkeit pada tahun 1962. Menurut Rundell (2005:220), Habermas mengemukakan gagasannya tentang ruang publik politik, yakni momen yang demokratis dalam masyarakat modern, sebagai fokus pemandu yang utama bagi upaya teoritis-filosofisnya.

Penelitian ini berupaya memaparkan secara lebih jauh bagaimana relasi antara ruang publik dan pers dalam pandangan Habermas hingga munculnya istilah jurnalisme publik sebagaimana yang dipahami saat ini. Karena itu, peneliti menyajikan penelitian ini dari mulai dasar pengertian ruang publik, relasi ruang publik dan pers, hingga pengeritan jurnalisme publik. Adapun penelitian dirumuskan dalam beberapa pertanyaan: (1) Bagaimana Dasar Ontologi Ruang Publik menurut Habermas?; (2) Bagaimana Sejarah ruang publik dan pers menurut Habermas?; dan (3) Bagaimana Konsep Jurnalisme publik dalam pandangan Habermas?

\section{Meta Analisis}

Penelitian ini adalah penelitian kepustakaan yang dilakukan dengan melakukan kegiatan interpretasi dan menggunakan jenis penelitian deskriptif-interpretif. Dalam penelitian ini, sudut pandang Jürgen Habermas digunakan untuk menganalisis objek penelitian. Objek penelitian itu sendiri adalah jurnalisme publik. Penelitian ini dibatasi 
dalam dua hal: (1) aspek ontologi ruang publik; dan (2) aspek sejarah jurnalisme publik.

Sumber data pada penelitian ini adalah kepustakaan yang berkaitan dengan objek penelitian. Literatur primer yang digunakan adalah karya Habermas yang langsung berhubungan dengan objek penelitian, antara lain: The Structural Transformation of the Public Sphere. Sedangkan literatur sekunder yang digunakan adalah literatur yang mengkaji pemikiran Jürgen Habermas, salah satunya karya trilogi F. Budi Hardiman (Kritik Ideologi, Menuju Masyarakat Komunikatif, dan Demokrasi Deliberatif).

Peneliti dalam penelitian ini adalah interpretator yang sekaligus berhadapan dengan kompleksitas bahasa, sehingga makna dan pesan yang terkandung dalam bahasa yang tidak jelas harus menjadi jelas (Kaelan, 2005:76). Upaya interpretasi ini juga digunakan karena Habermas tidak pernah secara langsung menulis atau secara khusus membahas jurnalisme publik, ia hanya menganalisis ruang publik dan pers di dalam karyanya. Jadi interpretasi digunakan untuk mendapatkan pemahaman tentang hakekat jurnalisme publik dengan menggunakan pemahaman Habermas tentang ontologi ruang publik. Menurut Bakker dan Zubair (1990:63), disinilah interpretasi berfungsi untuk menerangkan dan menerjemahkan karya seorang tokoh, yaitu untuk menangkap arti dan nuansa yang dimaksukan tokoh secara khas.

\section{Hasil Penelitian}

\section{Ontologi Ruang Publik}

Istilah publik mengalami perubahan seiring dengan bentuk-bentuk perkembangan masyarakat itu sendiri, dari masyarakat feodal hingga masyarakat liberal-demokratik. Dalam masyarakat Yunani, publik diartikan secara sederhana sebagai suatu kehidupan bersama. Pembagian struktur masyarakat dari Aristoteles (384-322SM) - kelas bawah (budak), prajurit, dan kelas terdidik (bangsawan) - misalnya, tidak serta merta membebaskan mereka untuk dapat saling hidup bersama dalam suatu hak yang sama di dalam ruang publik. Pembagian kelas sosial di Athena juga membedakan dengan tegas antara warga negara dengan warga asing (metic) (Schmandt, 2002:35). Warga asing memiliki hak yang sama dalam berbagai sisi kehidupan dengan warga negara asli Athena, namun mereka tidak diberi hak politik walaupun sudah menetap dalam kurun waktu yang lama. Begitu pula warga negara tidak menyiratkan seluruh warga yang lahir di Athena memiliki hak politik. Wanita, pedagang, maupun petani tidak dianggap sebagai warga negara yang memiliki hak politik dan urusan publik.

Dalam masyarakat Yunani - begitu pula dalam masyarakat feodal pada umumnya - pengertian publik lebih digunakan sebagai identitas bagi status keningratan. Istilah kepublikan hanya merujuk pada status sosial yang lebih tinggi (Habermas, 1989:4). Masyarakat yang diatur oleh kepercayaan raja sebagai wakil Tuhan di bumi tidak memiliki hak untuk menentukan hidup secara mandiri (merdeka). Raja dalam hal ini memiliki kekuatan absolut untuk menentukan hidup warganya 
dengan segala tugas dan status yang harus diemban. Siapa yang harus jadi pemilik tanah, siapa yang harus jadi mandor, dan siapa yang harus menjadi budak, atau buruh diatur sepenuhnya oleh kekuasaan mutlak raja. Demikian halnya urusan yang menyangkut kepentingan pribadi dalam rangka memenuhi kebutuhan ekonomi, kepemilikan atas harta, pada saat itu belum disebut dengan istilah privat. Istilah privat dalam kerangka feodalisme lebih merujuk pada hak-hak istimewa yang dimiliki sebagian orang, yaitu mereka yang dengan kekebalan hak dan keistimewaan tertentu dibebaskan dari apapun, terutama dari hukum (Habermas, 1989:6).

Kondisi ini terjadi karena masih kuatnya kepercayaan akan individu-individu pilihan yang berpengaruh pada pola pikir politik pada masa Yunani kuno hingga abad pertengahan. Menurut Aristoteles (Russell, 2004:253), sejumlah orang sudah ditentukan untuk takluk sedangkan yang lain ditentukan berkuasa; manusia yang ditentukan dan dimiliki orang lain sejak lahir adalah budak. Istilah privat pada saat itu lebih mengarah pada keistimewaan yang disandang kalangan tertentu. Raja dan keluarga-keluarga ningrat diberi kewenangan seluas-luasnya untuk menggunakan hak tersebut walaupun bertentangan dengan kehendak masyarakat umum. Penguasaan atas tanah secara penuh, bebas dari pajak, atau bebas dari hukum disebut sebagai bagian privat mereka. Sedangkan istilah 'ketuanan' pada abad pertengahan yang disandang oleh kelompok masyarakat kelas atas dianggap memiliki arti yang sama dengan istilah 'publikus', dan kepublikan diartikan sebagai memerlukan kehadiran seorang tuan (Habermas, 1989:10). Ketika raja berkumpul dengan pemuka agama, tuan-tuan tanah, maupun kalangan ningrat adalah sebagai bentuk dari kepublikan. Begitu pula ketika raja berdiri di hadapan rakyat tidak lain adalah sebuah 'pertontonan kepublikan' sebagai wujud dari perbedaan status diantara mereka. Hadir di depan publik artinya memperoleh pengakuan di hadapan masyarakat berkenaan dengan apa yang tokoh itu miliki, maka istilah tokoh publik (public figure) lebih diartikan sebagai tokoh atau orang yang memiliki keutamaan status sebagai orang kaya, penguasa, atau bangsawan.

Sejauh pengistilahan publik di atas, maka ruang publik dalam hal ini tidak lain hanyalah sebuah legitimasi atas perbedaan-perbedaan yang dimiliki manusia. Kelaskelas sosial yang ada dalam kehidupan masyarakat dianggap sebagai sesuatu yang wajar. Orang-orang yang berada dalam status sosial rendah tidak memiliki kesempatan untuk berbicara mengeluarkan pendapat, begitu pula status yang mereka sandang akan bertahan hingga kematiannya.

Pada kondisi berbeda, istilah publik dipahami secara berbeda. Menurut Habermas (1989:4), kondisi ini berbeda dengan yang ditemukan dalam hukum Roma Kuno dimana kategori mengenai wilayah publik dan privat sudah dipisahkan dengan tegas. Ruang publik yang dipahami sebagai res publica sudah terdefinisi dengan baik; res (urusan) dan publica (umum) memberi kerangka yang jelas mengenai istilah publik yang digunakan saat ini. Publik mulai diartikan sebagai urusan yang menyangkut kepentingan bersama, hajat hidup bersama, atau hidup dalam hak yang sama.

Kawasan Eropa pada abad ke-13 juga mulai mengenal pengertian ruang publik. Istilah Burg (kota benteng) yang dibangun oleh sebagian besar kalangan kapitalis 
(pedagang dan saudagar) Eropa merupakan cikal bakal ruang terbuka bagi masyarakat. Setiap warga (burger) yang tinggal di dalam kota memiliki hak yang sama. Mereka memiliki hak untuk berpendapat, hak politik, begitu pula mereka dapat berubah profesi, atau mengubah status sosial mereka. Mereka hidup berdampingan yang diatur oleh kesepakatan hukum bersama atau kode hidup bersama yang disebut Burgerlich. Kekuatan kelas menengah inilah yang menandai kemunculan ruang publik borjuis dalam pengertian yang disampaikan oleh Habermas. Istilah borjuis atau yang biasa disebut dengan kelas menengah mengacu pada kelompok masyarakat yang terdiri dari para pedagang atau saudagar. Sedangkan kehidupan bersama yang diatur oleh hukum atas kesepakatan warganya disebut Burgerliche Gesellschaft. Istilah tersebut kemudian dijadikan sebagai dasar dari konsep civil society.

Dalam ruang publik yang tinggal hanya kepentingan-kepentingan yang menyangkut masalah bersama. Istilah ruang publik atau yang dalam bahasa Jermannya; Offentlichkeit ini berarti "keadaan yang dapat diakses semua orang" dan mengacu pada ciri terbuka dan inklusif ruang ini (Hardiman, 2009:135).

Perkembangan ruang publik memperlihatkan sebuah proses masyarakat menuju pada kemampuan komunikasi bersama. Habermas (1989) membagi ruang publik ke dalam dua jenis; (1) ruang publik politik, dan (2) ruang publik sastra. Ruang publik politik bukan hanya memperlihatkan keterbukaan ruang yang dapat diakses, tetapi memperlihatkan pula bagaimana struktur sosial masyarakat yang berubah. Kelas-kelas sosial yang terbentuk dari sistem feodal lambat laun tidak dapat dipertahankan lagi. Sementara itu dalam ruang publik sastra, kesadaran literasi masyarakat mulai meningkat sejalan dengan kemunculan penerbitan-penerbitan, diskusi masyarakat mengenai seni, estetika, maupun sastra tersebar di penjuru Eropa.

Sekitar abad 18, di Eropa mulai berkembang ruang publik yang mampu menampung seluruh lapisan masyarakat dalam sebuah diskusi kritis. Ruang publik itu diwarnai dengan wacana-wacana kritis di dunia politik dan sastra yang datang dari berbagai kelompok, baik itu Tischgesellschaften (himpunan masyarakat) maupun Sparchgesselschaften (himpunan masyarakat sastra). Kedai-kedai kopi yang menjadi tempat pilihan mereka bukan hanya berfungsi sebagai ruang diskusi, tetapi berfungsi pula sebagai "tempat oposisi" dari ruang-ruang yang tidak bisa diakses oleh masyarakat umum seperti halnya istana, gedung parlemen, maupun teater musik kaum ningrat. Tahun 1680 hingga 1730 misalnya, di Inggris berkembang kedai kopi yang pada awalnya sebagai kritik di dunia sastra namun di kemudian hari merambah ke wilayah politik. Hal ini tidak lepas dari peranan kelompok terdidik yang mulai muncul sebagai "borjuis baru" diantara aristokrat dan intelektual borjuis (Habermas, 1989:32). Kelas-kelas yang tadinya tidak diperhitungkan peranannya dalam masyarakat mulai mendapatkan tempat yang bebas untuk berdialektika dalam berbagai wacana.

Berbagai kelompok pembaca yang berkumpul di kedai kopi, himpunan masyarakat pada dasarnya memiliki hak dan kebebasan yang sama. Pemandangan ruang publik di Eropa ini menurut Habermas (1989:36-37) memiliki tiga kriteria sebagai ruang publik masyarakat. Pertama, mereka mengesampingkan perbedaan 
status sosial dan memunculkan prinsip-prinsip kebersamaan dan kesetaraan sebagai semangat setiap pertemuan-pertemuan diantara mereka. Stratifikasi sosial yang menempatkan kalangan pedagang sebagai masyarakat kelas menengah (borjuis) mulai berubah. Pengunjung yang datang ke kedai-kedai kopi tidak hanya datang dari kalangan borjuis saja, namun para pegawai, pemilik toko, serta kaum profesional dan masyarakat lainnya pun ikut berkumpul. Istilah borjuis kemudian meluas tidak hanya sebatas saudagar. Strata baru masyarakat borjuis lahir dan segera menempati posisi sentral di dalam publik (Habermas, 1989:23). Setiap individu yang datang ke ruang publik tersebut diberikan kesempatan berpendapat mengenai persoalan-persoalan yang menyangkut wilayah privat maupun wilayah publik. Dalam kondisi ini, ruang publik memiliki peranan utama sebagai pendorong bagi kemampuan komunikasi setiap lapisan masyarakat. Oleh karena itu, ruang publik politik dan ruang publik sastra yang diadakan di kedai-kedai kopi ini mejadi tempat komunikasi pertama yang bebas dari tekanan kekuasaan.

Kedua, ruang publik membuka wacana-wacana yang belum pernah dipersoalkan, seperti monopoli negara dan gereja atas interpretasi kebenaran dalam teks. Kekuatan-kekuatan sosial baru dalam masyarakat mulai membawa ruang publik sastra ke dalam wilayah politis. Karya-karya seperti puisi, novel, cerpen, musik, maupun teater mulai dijadikan alat bagi perlawanan atas otoritas negara yang absolut. Begitu pula jurnal-jurnal yang dihasilkan dari ruang publik sastra mulai gencar melakukan kritik. Menurut Habermas (1989:41), jurnal-jurnal kritik seni dan budaya merupakan karya yang mengesankan di abad ke-18 sebagai instrumen-instrumen yang melembagakan kritik sastra. Bahkan dalam ruang publik politis, penghapusan lembaga sensor di Inggris sekitar tahun 1694-1659 dianggap sebagai kemajuan perkembangan ruang publik. Perkembangan jurnal, pamflet, maupun pers pada ruang publik politik mulai menunjukan prospeknya sebagai lembaga mandiri. Sebut saja Diskurse der Mahlern, sebuah jurnal mingguan yang diterbitkan oleh Bodmer dan Breitinger di Zurich pada 1721 yang muncul dari hasil-hasil pertemuan di kedai-kedai kopi.

Dengan semakin meningkatnya komunikasi dan daya kritis masyarakat, Pemerintah tidak dapat menghadapi masyarakat secara otoriter. Pemerintah Inggris misalnya, mulai membuat terbitan tandingan. Beberapa media pemerintah seperti London Gazette (1704), Examiner (1711), atau London Journal (1722) diterbitkan untuk menghadapai pers oposan seperti Gulliver, Dunciad, Fables, dan Gentleman's Magazine (Habermas, 1989:60). Perdebatan kritis di wilayah politik (pemerintah dengan masyarakat) menempatkan pers-pers oposisi sebagai "kekuatan keempat" dalam rangka mengemban tugas sebagai otoritas publik. Istilah "kekuatan keempat" atau "the fourth estate" di dalam setiap literatur jurnalisme, kini diartikan sebagai kekuatan penyeimbang dari tiga kekuatan lain, yakni; eksekutif, legislatif, dan yudikatif. Namun menurut Wiryawan (2007:69), istilah the fourth estate yang dikemukakan seorang negarawan Inggris Edmund Burke pada abad ke-18 di Parlemen Inggris, merujuk sistem kekuasaan zaman feodal di mana terdapat tiga kekuatan, yaitu lords spiritual (pendeta), lord temporal (bangsawan) dan the commons (kelas 
menengah-borjuis). Edmund Burke menyebut para wartawan di sebuah lorong gedung parlemen sebagai kekuatan keempat.

Ketiga, pertemuan individu di dalam ruang publik sastra telah mengubah kebudayaan menjadi komoditas. Kebudayaan yang dimaksud Habermas adalah budaya tulis (jurnal maupun pamflet), budaya musik dan teater. Musik dan teater pada abad ke-18 masih dianggap sebagai sesuatu yang elit, glamor, dan hanya bisa dinikmati oleh golongan bangsawan. Bagi Habermas (1989:39) apa yang sekarang kita sebut musik klasik, dahulu memiliki fungsi sosial, baik sebagai kesakralan dan martabat penyembahan maupun semarak perjamuan. Oleh karena itu tidak ada akses bagi masyarakat terhadap musik dan teater. Namun akibat dari kemajuan ruang publik sastra, lambat laun akses semakin terbuka, bahkan masyarakat menciptakan musik dan teater secara mandiri. Pada tahun 1766 misalnya, di Jerman didirikan Deutsches Nationaltheater (Teater Nasional Jerman) yang dapat diakses oleh penonton umum, begitu pula Collegia Musica muncul sebagai "musik publik" pertama di Jerman, dimana karcis masuk yang harus dibayar mengubah performa musik menjadi komoditas (Habermas, 1989:39).

Perubahan musik dan teater ke arah komoditas menunjukan kritik masyarakat atas seni yang selama masa itu didominasi kelompok-kelompok tertentu. Lebih jauh lagi, perubahan ke arah komoditas ini menunjukan kesadaran masyarakat akan kesamaan hak yang mampu menempatkan musik dan teater sebagai milik publik dan bukan sebagai alat stratifikasi sosial.

Perubahan budaya tulis menjadi komoditas di sisi lain menunjukan watak yang berbeda. Jika musik dan teater berkembang ke arah komoditas sebagai bentuk perlawanan kelas atas hak dan kebebasan, budaya tulis sendiri menjadi komoditas karena murni kepentingan kapitalis. Pengelola pers pada saat itu mulai menyadari bahwa mereka memiliki publik yang sangat banyak, dan fungsi pers sebagai ruang komunikasi pun diarahkan pada pembentukan tema-tema diskusi yang dapat diikuti oleh seluruh kalangan. Akhirnya pembentukan tema-tema ini menjadi potensi pasar yang sangat besar.

\section{Ruang Publik Dan Pers}

Kemunculan pers diawali dengan kegiatan penulisan pamflet oleh individu-individu sejak abad ke-16, yang juga memiliki keterkaitan dengan perkembangan ruang publik politik dan ruang publik sastra. Pada awalnya, penerbitan pamflet di beberapa negara di Eropa dilakukan tanpa jadwal tetap. Penerbitan dilakukan secara aksidental sebagai respon atas realitas yang terjadi pada waktu itu. Di Inggris sendiri, penerbitan yang dikelola oleh kelompok-kelompok masyarakat baru dapat melakukan publikasi secara rutin sekitar abad ke-17. Antara 1620 hingga 1660, organisasi-organisasi penerbitan mulai memperhatikan jadwal rutin terbit tersebut (Berry, 2008:19). Fase ini kemudian dijadikan patokan oleh para peneliti sejarah pers sebagai kemunculan surat kabar (newspaper) pertama sebagai lembaga pers tertua. Jadi dalam hal ini, pendefinisian awal mengenai apa yang disebut pers tidak lain adalah persoalan rutinitas penerbitan. 
Ia disebut pers minimal jika terbit sekurang-kurangnya seminggu sekali (Berry, 2008:20). Kriteria-kriteria itu kemudian berkembang; apa yang disebut pers tidak lagi sebatas jadwal penerbitan yang rutin, namun mulai diperhatikan pula persoalan jenis berita yang disajikan, serta yang terpenting ialah konsistensi dan format penerbitan yang mampu dikenali oleh masyarakat pembaca (terbentuknya identitas media penerbitan).

Embrio kemunculan pers yang digambarkan Habermas sendiri memiliki dua kemungkinan yang berbeda, yang dikemudian hari membuka perdebatan perihal industrialisasi media dan wacana tentang media publik atau yang lebih populer dengan istilah jurnalisme publik. Secara keseluruhan istilah jurnalisme sendiri muncul pada abad ke-18 dengan merujuk pada jenis penulisan baru yakni penulisan yang mengarah pada kegiatan atas pengelolaan informasi (Eaman, 2009:46). Habermas sendiri merujuk kemunculan pers pada fase kapitalisme awal di abad ke-13 dan secara tegas mengalamatkan kegiatan tersebut pada kebutuhan-kebutuhan yang mendukung proses perdagangan para saudagar (merchant). Di sisi lain, analisis Habermas tentang ruang publik di wilayah sastra membuka kemungkinan bahwa pers pada mulanya merupakan sebuah kegiatan kritis yang dilakukan masyarakat di dalam ruang publik. Jadi secara garis besar kemunculan pers dapat dibagi ke dalam dua embrio: pertama, kemunculan pers yang berkaitan dengan kegiatan kapital; dan kedua, berkenaan dengan aktifitas individu-individu di dalam ruang publik sastra.

Kegiatan kapital yang dilakukan para saudagar pada mulanya bersumber dari pengelolaan tanah yang melibatkan hubungan antara pemilik dengan petani. Hasilhasil dari pengelolaan tanah pertanian maupun perkebunan dipasarkan di wilayah yang tidak begitu jauh dari tempat pengelolaan. Oleh karena itu kapitalisme awal biasanya hanya berbentuk pertukaran komoditas sederhana. Dalam beberapa literatur seperti Capitalism and its Economics: A Critical History (2000), Capitalism; Very Short Introduction (2004), atau Encyclopedia of Capitalism Volume I (2004) Inggris sering dijadikan rujukan sebagai tempat awal kemunculan kapitalisme. Argumen ini tentu sangat beralasan sebab seperti yang dikatakan James Fulcher (2004:21), revolusi industri yang terjadi di Inggris membuka pertumbuhan produksi, konsumsi dan juga pasar perdagangan. Begitu pula disampaikan Douglas Dowd (2000:20) bahwa Inggris lebih memiliki modal dasar untuk menuju industri kapitalis dibanding negara lain seperti Prancis. Perubahan instiutusional di Inggris yang terjadi sekitar tahun 1640-an juga menjadi sebab bagi terbukanya kondisi sosial-ekonomi yang lebih fleksibel untuk menuju pada industri modern.

Membludaknya hasil produksi yang disebabkan perubahan cara produksi mendorong perdagangan tidak hanya dilakukan dalam jarak yang dekat. Tahun 1601 misalnya, English East India Company (kongsi dagang) melakukan ekspedisi perdagangan yang pertama ke wilayah Asia hingga ke Sumatera dan Jawa (Fulcher, 2004:1). Pembukaan pasar-pasar baru yang sangat menguntungkan kapitalis ini di sisi lain menyisakan masalah komunikasi dan informasi. Keterbatasan sarana komunikasi pada saat itu sangat menghambat kegiatan perdagangan. Mereka terbatas mengetahui 
informasi tentang permintaan barang di wilayah yang mereka datangi. Dalam kondisi seperti ini, keberadaan orang-orang pengirim surat menjadi sangat penting. Mereka ditugaskan untuk pergi lebih awal ke tempat di mana perdagangan akan dilakukan, kemudian memberikan informasi kepada dua belah pihak yang akan bertemu untuk melakukan transaksi. Kegiatan pengiriman "surat awal" ini lazimnya disebut ordinary mail (Habermas, 1989:16).

Kegiatan publikasi berita yang diperuntukkan bagi masyarakat umum (publik) menurut Habermas mulai signifikan pada akhir abad ke-17, di Inggris mulai bermunculan newsletter dan jurnal-jurnal berkala seperti Acta Euditorum Otto (1682), di Prancis Journal des Savants (1665), dan di Jerman ada Hallenser Intelligenzblatt (1729). Kemunculan newsletter dan jurnal-jurnal ini tentunya didukung oleh kemampuan mesin percetakan dengan kekuatan tinggi. Mesin cetak dari plat kayu yang diciptakan pada tahun 1439 oleh Johann Gutenberg (1400-1468) mulai dikembangkan inovasinya. Pada tahun 1620-an kecepatan percetakan meningkat secara mengesankan dengan kemampuan cetak dari 15 hingga 150 eksemplar per jam (Eaman 2009:16). Di Inggris sendiri, jasa-jasa pelayanan percetakan sudah mulai tumbuh sekitar tahun 1487 di bawah kontrol pemerintah, sedangkan di Amerika usahausaha percetakan ini mulai menggeliat sekitar tahun 1815 (Turow, 2009:267).

Embrio kedua dari kemunculan pers atau aktivitas jurnalistik adalah kegiatankegiatan diskusi publik yang diadakan di kedai-kedai kopi yang disebut sebagai ruang publik sastra. Pengertian sastra di sini merujuk pada kegiatan individu-individu privat dalam membaca dan menulis, serta menuangkan gagasan dalam bentuk diskusi dan penerbitan. Pertemuan di kedai-kedai kopi tersebut dihadiri oleh masyarakat dari berbagai kalangan, baik itu pengusaha, pedagang, buruh, maupun para profesional. Keterlibatan mereka di dalam forum-forum diskusi ini memberikan dampak yang sangat besar bagi perubahan sosial, politik maupun ekonomi. Di Inggris misalnya, sejak tahun 1652 kedai-kedai kopi sudah mulai berkembang. Kemunculannya tidak lepas dari dampak Revolusi Inggris yang berlangsung pada tahun 1640-an (Eaman, 2009:27).

Pamflet merupakan media komunikasi yang berkembang sekitar abad ke-16. Pamflet ini biasanya memuat tulisan-tulisan kritis mengenai kritik politik, sosial, ekonomi, agama maupun sastra dan seni. Biasanya pamflet dibuat hanya berbentuk lembaran kecil dengan jumlah halaman yang sedikit. Menurut Eaman (2009:272) perkembangan pamflet ini sangat cepat terutama di Inggris karena biaya produksi yang dikeluarkan tidak terlalu besar. Pengelolaan pamflet tersebut biasanya dilakukan oleh organisasi-organisasi masyarakat atau asosiasi-asosiasi secara independen. Dalam beberapa kasus, pengelolaan ini bahkan dipegang oleh individu-individu dalam jumlah yang sangat kecil. Mereka harus menjalankan tugas yang sangat padat dari mulai sebagai penulis, editor, sampai berurusan dengan percetakan.

Pengaruh kegiatan penulisan pamflet terhadap kehidupan sosial politik direspon penguasa dengan melakukan tekanan terhadap para pelakunya. Raja Frederick II (Prusia) pada tahun 1784 mulai mengeluarkan peraturan mengenai 
keberadaan media-media tersebut (Habermas, 1989:25). Dalam peraturannya, seorang individu tidak boleh menuangkan gagasannya kepada publik mengenai hukum, regulasi, dan kekuasaan pemerintah, serta raja dan para pejabat, atau menyebarluaskan dalam bentuk cetakan laporan. Larangan penyebaran gagasan ini karena seorang individu dianggap tidak kompeten dalam membuat penilaian. Tidak kecuali tulisan dari kalangan intelektual pun harus melalui pengawasan pemerintah (sebelum diterbitkan). Hal ini barangkali cukup beralasan bagi penguasa, sebab keberadaan pamflet semakin lama semakin tumbuh secara pesat. Ikatan-ikatan pembaca pamflet di setiap kota-kota sudah mulai kuat pengaruhnya dalam melancarkan opini publik. Menurut Berry (2008:29), para penulis pamflet sudah mulai kritis dalam melakukan kritik terhadap pemerintahan, sebut saja penulis pamflet radikal dari Inggris Thomas Paine (1737-1809) yang dengan gigih mengkampanyekan kemerdekaan Amerika dari kolonialisme Inggris, atau Daniel Dafoe yang sering melakukan kritik secara radikal dalam pamfletnya terhadap tradisi Gereja Anglikan.

Secara umum pelarangan atau sensor ini biasanya menyangkut masalah kontrol pemerintah terhadap akses publik, penyebaran informasi dan gagasan-gagasan, juga persoalan-persoalan rahasia yang menyangkut kepentingan pemerintah (Eaman, 2009:32). Bentuk-bentuk penyensoran ini tidak lain sebagai bagian dari usaha pemerintah, baik itu di Inggris, Perancis, maupun Jerman untuk mempertahankan kekuasaan absolut di masyarakat. Kontrol atas penerbitan di Inggris sendiri mencapai puncaknya di bawah kekuasaan Henry VIII hingga masa Ratu Elizabeth I. Mereka melakukan kontrol terhadap penerbitan terutama untuk menyetir dan mengalahkan kelompok-kelompok yang beroposisi dengan kekuasaan. Kontrol ini terus berlanjut hingga abad ke-17 dimana perang sipil yang terjadi di Inggris mengubah kondisi sosial politik pada saat itu. Praktik sensor ini memang telah menjadi senjata politik sejak ratusan tahun yang lalu. Gereja Katolik Roma pun pernah mengeluarkan daftar bukubuku yang dilarang beredar sejak abad ke-6, dan sensor tersebut baru dicabut pada abad ke-20. Di Belanda dan Jerman para penulis pamflet merasakan praktek penyensoran ini sejak abad ke-18. Sementara itu di Perancis sensor mulai diterapkan sejak abad ke-19 ketika koran-koran mulai bermunculan. Pada saat itu banyak kegiatan penerbitan yang kemudian ditutup, bahkan wartawannya dipenjarakan. Memasuki tahun 1800-an misalnya, Napoleon menutup 73 koran dan mendirikan penerbitan pemerintah - Moniteur Universel - untuk mengendalikan 100 koran dan mengontrol opini publik. Hukum pers dan sensor di Perancis ini baru mulai diliberalisasikan dan kebebasan berekspresi mulai dihargai pada tahun 1881 (Steel, 2009:586).

Pelaksanaan sensor terhadap penerbitan tidak bisa dipisahkan dari bentukbentuk sistem politik yang dianut oleh setiap negara. Pemerintahan yang menerapkan sistem otoritarian dengan yang menerapkan sistem demokrasi tentu memiliki regulasi yang berbeda terhadap pengendalian pers.

Walaupun kontrol maupun tekanan dari kekuasaan terhadap penerbitan pamflet terus berlangsung, hal ini tidak menyebabkan individu-individu surut dalam melakukan penerbitan tulisan-tulisan. Mereka menyadari bahwa kegiatan penulisan 
dan penyebaran pamflet merupakan jalan yang sangat efektif untuk menunjang kegiatan komunikasi dan pembentukan opini publik, bahkan sekitar tahun 1860-an, penerbitan-penerbitan yang dikelola oleh partai politik kian menjamur, seperti di Inggris, Perancis maupun Jerman (Habermas, 1986:186). Individu-individu yang aktif di dalam partai politik tidak menyerahkan tulisan mereka kepada para pengelola pamflet, mereka lebih memilih untuk mengelolanya sendiri. Kepentingan politik maupun ekonomi yang sangat besar mendorong mereka untuk membentuk suatu opini publik yang menguntungkan bagi mereka. Pada saat itu pertarungan opini di antara para penulis pamflet dengan politikus maupun penguasa semakin memanas. Di sisi lain, tema-tema seperti politik, sosial, ekonomi, maupun agama menjadi bahan yang terus dikembangkan guna keuntungan pengelolaan penerbitan. Kemunculan beritaberita dalam membangun kesadaran kolektif masyarakat dan kesadaran politik pada akhirnya menjadi potensi komersil yang nyata (Steel, 2009:587). Berita kemudian menjadi komoditas, dan komodifikasi ini memberikan dampak yang sangat besar bagi aspek bisnis kegiatan jurnalisme yang pada mulanya sebagai sumber kekuatan opini dan politik publik.

Di akhir abad ke-17 dan memasuki abad ke-18, pamflet kemudian berubah bentuk menjadi surat kabar (newspaper). Perubahan ini awalnya dimulai dengan penggabungan pamflet-pamflet dalam jumlah halaman yang kecil menjadi bentuk terbitan dalam halaman yang lebih banyak (pada saat itu dikenal dengan sebutan newsbooks). Namun, karena newsbooks masih dianggap kurang memadai untuk menampilkan informasi yang lebih banyak, maka surat kabar pun dibentuk dengan ukuran dan jumlah halaman yang lebih banyak. Usaha-usaha penerbitan surat kabar untuk mencari keuntungan kemudian mulai dikembangkan oleh para pengusaha, bahkan oleh keluarga dalam bentuk usaha rumah tangga. Pada 1816 koran-koran kemudian dicetak untuk pertama kalinya dalam jumlah yang besar; 50.000 eksemplar (Habermas, 1989:168). Reputasi penerbitan kemudian tidak lagi bertumpu pada kemampuan pewarta atau editor seperti yang dilakukan oleh individu-individu penulis pamflet, tetapi lebih dilihat berdasarkan popularitas surat kabar. Proses komodifikasi ini membawa dampak pula bagi kemunculan peredaran surat kabar pertama di berbagai negara. Persaingan antar pernerbit pun kian membesar ketika teknologiteknologi baru mulai bermunculan. Pers terus berkembang menjadi ruang dalam penyampaian opini publik, hingga kemudian konsep jurnalisme publik dikenal.

\section{Jurnalisme Publik}

Konsep jurnalisme publik dikembangkan oleh beberapa peneliti untuk memahami bagaimana proses kerja dan pengertian jurnalisme publik itu sendiri. Iggers (1999:144) membagi pengertian jurnalisme publik ke dalam dua bagian: (1) public journalism as journalism about the public; dan (2) public journalism as journalism with the public.

Pengertian jurnalisme publik yang pertama adalah bagaimana pers membangun wacana yang menyangkut kepentingan publik terutama dalam partisipasi politik. Dalam wacana tersebut, pers mendorong, masyarakat agar dapat terlibat dalam 
segala urusan publik, sehingga segala keputusan atau kebijakan yang dikeluarkan pemerintah dapat dilakukan melalui proses demokrasi deliberatif. Upaya ini merupakan bentuk tanggung jawab dan tujuan pers sebagai instrumen pokok di masyarakat.

Jurnalisme publik ini menjadikan informasi yang disampaikan tidak sekedar menjadi komoditi, tetapi memiliki nilai budaya dan pendidikan (Haryatmoko, 2007:158). Peran jurnalisme publik dalam pelaksanaan demokrasi deliberatif adalah membangun partisipasi politik yang berkelanjutan. Demokrasi tidak hanya dipahami sebatas pada pelaksanaan pemilu semata, tetapi merupakan bentuk keterlibatan individu sebagai warga negara dalam setiap pengambilan kebijakan. Di sini, peranan pers sebagai fourth estate tidak hanya dilakukan sendiri, tetapi dibantu kekuatan besar dari masyarakat. Setiap kebijakan yang dikeluarkan pemerintah secara deliberatif diuji di hadapan publik. Pemerintah tidak serta-merta mengeluarkan kebijakan atas dasar legalitas politik kekuasaan, tetapi atas legalitas publik. Semakin sering kebijakan itu diuji oleh publik, semakin kuat legitimasi kebijakan itu di hadapan publik. Jadi, legitimasi tidak terletak pada hasil komunikasi politik, melainkan pada prosesnya (Hardiman, 2009:130). Deliberasi juga tidak mendasarkan keputusan-keputusan publik pada konsep mayoritas dalam artian kuantitas (jumlah kelompok), misalnya, pemerintah mengeluarkan satu kebijakan karena desakan dari partai mayoritas atau partai pemenang pemilu. Mayoritas dalam pengertian deliberatif lebih mengarah pada dorongan yang datang dari seluruh partai, kolompok agama, maupun golongan, baik mereka itu mayoritas maupun minoritas. Artinya kesepakatan diambil bukan dalam konteks pertarungan jumlah pendukung, tetapi atas dasar kesepakatan bersama.

Pada tahun 1990an, dua jurnalis Amerika, Joy Rosen dan Davis Merrit mengembangkan konsep jurnalisme publik dalam pengertian deliberatif ini. Mereka melihat bahwa semakin lama publik semakin teralienasi dan tersingkir dari aktifitas politik dan kehidupan publik (Eaman, 2009:241). Tersingkirnya masyarakat dari aktifitas politik ini bisa jadi karena jauhnya wilayah mereka dari kota atau pusat aktifitas politik. Bisa juga karena wacana-wacana politik telah didominasi oleh elitelit politik, ahli-ahli politik, maupun pengamat politik. Dominasi ini menyebabkan hilangnya kesempatan bagi masyarakat biasa untuk berpartisipasi dan meningkatkan kemampuan komunikasi mereka. Dominasi ini jelas sangat berbahaya karena rentan terhadap dua hal, yaitu komersialisasi dan pelacuran oportunitas politik (MagnisSuseno, 2004:10). Masyarakat Indonesia yang berada di pelosok misalnya, sulit untuk menyampaikan aspirasi kepada pemerintah pusat karena media komunikasi sangat terbatas. Tidak terkecuali, dominasi elit-elit politik lokal terkadang membuat mereka enggan untuk menyampaikan aspirasi, terlebih lagi kritik, karena rentan dengan tekanan dan intimidasi. Di sinilah jurnalisme publik dapat memainkan peranannya untuk membangun wacana-wacana yang berkaitan dengan kepentingan publik dan melancarkan keran-keran demokrasi yang tersumbat.

Para pendukung konsep jurnalisme publik memaknai praktek tersebut sebagai tipe jurnalisme yang mendorong peningkatan partisipasi publik, debat publik, juga 
meningkatkan kehidupan publik, namun tanpa mengorbankan independensi (Mwangi, 2009:671). Maksudnya, tidak karena dalih kebebasan pers, media memainkan wacanawacana yang malah menjauhkan mereka dari kepentingan publik. Independensi di sini pun dimaksudkan agar pers benar-benar jeli dalam membangun wacana yang datang dari publik, bukan malah terpancing oleh wacana-wacana yang dibangun kelompok tertentu. Karena itu, baik pers maupun masyarakat harus benar-benar mamahami makna dari kebebasan pers dan kebebasan berekspresi itu sendiri.

Konsep kedua dari jurnlisme publik adalah public journalism as journalism with the public. Dalam hal ini, jurnalisme menjadikan masyarakat sebagai rekan aktif, baik itu dalam proses pembuatan berita, maupun dalam rangka membangun kemampuan masyarakat untuk bekerjasama dalam menyelesaikan masalah-masalah atau dalam rangka mencapai target-target yang masyarakat inginkan (Iggers, 1999:149). Jika pada pengertian sebelumnya jurnalisme publik lebih mengarah pada bentuk partisipasi politik yang berkaitan dengan kebijakan dan persoalan legitimasi pemerintah, maka dalam bagian ini, partisipasi tidak hanya bekerja di wilayah politik. Permasalahan yang menjadi kepentingan publik seperti pendidikan, kesehatan, hak asasi manusia, dan lainnya diakomodasi dalam ruang perbincangan bersama dengan pers.

Jurnalisme bersama dengan masyarakat pun dapat diarahkan pada pembentukan dan dukungan bagi terciptanya open public conversations, seperti lingkar studi, dialog komunitas, maupun forum-forum publik. Bentuk-bentuk ini pada dasarnya tidak jauh berbeda dengan kedai-kedai kopi, klub-klub baca, maupun bentukbentuk perkumpulan lainnya di abad ke-18 yang dipotret oleh Habermas. Pers, warga, dan lembaga swadaya berkumpul dalam satu ruang untuk membicarakan persoalan publik. Mengenai hal ini Iggers (1999:150) memberikan contoh: pada tahun 1994, kerjasama antara Wisconsin State Journal, Madison, Wisconsin Public Radio, Wisconsin Public Television, dan CBS membangun sebuah proyek bersama (We the People) yang bertujuan untuk mengorganisir forum-forum publik yang ada di Madison mengenai masalah kesehatan, kejahatan, anggaran negara, dan electoral contests. Donatur proyek The Pew Charitable Trust secara langsung mengevaluasi terhadap proyek tersebut. Mereka menemukan dampak positif dari kegiatan tersebut terhadap kehidupan publik dan kesadaran warga. Proyek itu melaporkan bahwa kegiatan itu (forum-forum publik dan pertemuan-pertemuan) telah membuat warga berperan aktif di dalam politik (sebesar 62\%) dan mendorong warga untuk terus mengembangkan Madison menjadi lebih baik sebagai tempat tinggal mereka.

Kegiatan jurnalisme bersama warga juga dicontohkan oleh Santana (2005:27), Red Batario (redaktur The Manilla Chronicle) membuat ilustrasi. Ketika sebuah kelurahan kekurangan air, berita bukan cuma memaparkan soal kelangkaan penyediaan air. Perlu pula dicari berita di kelurahan lain, yang punya soal yang sama tetapi telah berhasil menyelesaikan masalah kekurangan air. Kedua publik di kelurahan yang berbeda itu dihadirkan. Keduanya sama-sama memaparkan persoalan. Keduanya diletakkan sebagai narasumber. Publik yang lain, di wilayah yang lain, mendapat 
keutuhan kisah yang langsung dari publiknya. Juga solusi yang langsung dari wacana soal publik itu sendiri.

Peran sebagai fasilitator ini pun dapat dikuatkan melalui diskusi bersama antara wartawan, para ahli, dan publik itu sendiri. Wartawan mengarahkan pertanyaannya kepada para ahli lingkungan, misalnya, "apa yang harus kami lakukan dengan persoalan air ini?", atau "apakah jawaban yang diberikan para ahli sekarang pernah dilakukan oleh orang lain sebelumnya, atau oleh orang di tempat lain?". Dialog-dialog seperti inilah yang akan mengembangkan kemampuan komunikasi masyarakat, menciptakan komunitas-komunitas yang peduli terhadap berbagai persoalan, dan pada akhirnya menciptakan kemandirian masyarakat.

Penelitian yang dilakukan oleh Chris Atton (2002) tentang media alternatif dan media radikal pada tahun 1990-an di Inggris dan Amerika menunjukkan, masyarakat mampu mengorganisir diri melalui media yang diciptakan sendiri. Meski hanya dibekali dengan peralatan dan kemampuan jurnalistik yang sederhana, mereka mampu membangun komunikasi antar individu maupun antar kelompok tanpa harus terus bertumpu pada media massa yang dijalankan oleh wartawan profesional. Dari hasil penelitiannya, Atton menemukan beberapa ciri dari media alternatif tersebut, diantaranya: Tidak untuk mencari keuntungan (non-commercial); Informasi dibuat sebagai counter-information dan untuk mendukung gerakan; Fokus pada tanggung jawab sosial dan ekspresi-ekspresi kreatif; Sebagai advokasi dan grassroots media; Editor dan para penulis bebas dari partai politik; Bukan ditujukan untuk kepentingan sempit atau kepentingan kelompok; Para pengelola adalah aktivis; Perbedaan antara pengelola dengan pembaca terkadang kabur; Distribusi dilakukan secara sembunyisembunyi (underground); dan anti-copyright (Atton, 2006:19-29).

Media alternatif dibuat tanpa ada kepentingan komersial. Urusan keuangan hanya sebatas bagaimana mereka dapat terus survive untuk memproduksi media tersebut. Keuangan yang mereka peroleh biasanya bersumber dari kegiatan musik maupun donatur. Mereka yang mengelola media alternatif seringkali memiliki grup musik yang cukup laku jika mau dijual secara massal. Namun mereka menolak hal itu, kegiatan musik hanya dilakukan untuk mendukung produksi media. Sedangkan donatur biasanya datang dari pihak-pihak yang simpatik terhadap kegiatan mereka. Format media alternatif ini sangat sederhana, biasanya dalam bentuk pamphlet, booklet, maupun leaflet, dan juga dengan jumlah halaman terbatas. Mereka mengisinya dengan berita, artikel, karikatur, maupun gambar. Proses pembuatan dilakukan dengan biaya seminimal mungkin.

Habermas memulai pemaparan mengenai relasi ruang publik dan pers dengan mengkaji pengertian-pengertian tentang ruang publik. Dalam masyarakat feodal, publik dipahami sebagai status sosial yang bersifat keningratan. Kalangan penguasa dan gereja adalah orang-orang publik yang memiliki hak istimewa di hadapan masyarakat umum. Pada masyarakat feodal ini, Habermas memandang bahwa antara ruang publik dan ruang privat belum terdapat pemisahan yang jelas.

Pemisahan ruang publik dan privat baru mulai ditemukan pada masyarakat 
Romawi di mana publik benar-benar ruang tempat kepentingan-kepentingan publik diperjuangkan. Sementara itu privat menjadi urusan pribadi setiap individu. Di dalam ruang publik, masyarakat dapat berdiskusi, melakukan kritik dan menyampaikan pendapatnya. Ruang publik menjadi tempat yang bisa diakses oleh semua orang, bersifat terbuka, dan inklusif. Konsep ruang publik ini diterima sebagai ruang demokratis hingga saat ini.

Pemaparan Habermas mengenai ruang publik dan pers tidak lepas dari tinjauannya mengenai perkembangan kapitalisme di Eropa. Kapitalisme awal di abad ke-17 memperlihatkan pertemuan antara kepentingan-kepentingan masyarakat di ruang publik, dengan pers sebagai saluran aspirasi publik. Pengelolaan informasi dimulai dari hal sederhana yang langsung berkaitan dengan kepentingan bisnis, seperti informasi mengenai barang dagangan yang diperlukan masyarakat.

Sebagaimana yang dianalisis Habermas, ruang publik dan saluran publik sebagai tempat pertemuan masyarakat lambat laun bertransformasi seiring dengan perkembangan teknologi. Salah satu saluran publik yang hingga saat ini besar sekali manfaat dan pengaruhnya bagi masyarakat adalah pers. Kelahiran pers di Eropa, terutama di Inggris, Perancis, dan Jerman, telah mengubah struktur sosial masyarakat. Masyarakat yang pada awalnya sangat feodal, lambat laun kekuatannya mulai berkurang. Peranan kaum borjuis sangat besar dalam melakukan transformasi tersebut. Mereka membuka ruang publik sastra di mana individu-individu dapat berkumpul dan mendiskusikan berbagai persoalan yang menyangkut kehidupan bersama. Dari ruang sastra inilah ruang publik politis muncul, dan dianggap sebagai cikal bakal semangat kemunculan pers. Di dalam ruang publik sastra, setiap individu privat diberi hak yang sama dalam menyampaikan pendapat, pandangan, maupun kritik. Begitu pula orangorang yang datang ke kedai-kedai - sebagai tempat di mana ruang publik sastra berlangsung - tidak hanya didominasi oleh kalangan borjuis, tetapi terbuka untuk seluruh masyarakat umum. Perkembangan pers ini pada akhirnya mengubah apa yang disebut sebagai kelas menengah (borjuis). Ia bukan hanya berasal dari kalangan pedagang sebagaimana makna awalnya, tetapi sudah menyebar meliputi kalangan intelektual, para pekerja, maupun pegawai. Pemisahan antara ruang publik dan ruang privat pun sudah mulai dilakukan.

Publik yang awalnya bermakna keunggulan dalam hal status sosial, kemudian berubah menjadi tanggung jawab pemerintah dalam mengelola urusan publik. Agama yang dulunya berada di bawah kekuasaan mutlak gereja, pada akhirnya ditempatkan sebagai ruang privat. Alhasil, pemuka agama tidak mendapatkan tempat dalam urusan politik dengan raja sebagaimana yang dilakukan sebelumnya. Semua perubahan ini tidak lepas dari peranan individu-individu privat yang aktif di dalam ruang publik sastra untuk mengembangkan pers sebagai ruang publik.

Memasuki era kapitalisme terutama di abad ke-17, ruang publik mulai mendapat ancaman. Ancaman yang dimaksud bukan dalam pengertian sensor dari kekuasaan, tetapi ancaman dari komersialisasi pers sebagai ruang publik kritis. Habermas melihat bahwa komodifikasi yang dilakukan oleh kalangan pengusaha 
terhadap berita dan pers menjadikan ruang-ruang kritis masyarakat semakin berkurang. Pers kini lebih banyak memuat berita-berita tentang kejahatan, seks, gosip, maupun hal-hal yang sensasional. Hal ini terjadi karena dalam perkembangannya, pers terus mengalami peningkatan dari segi jumlah pembaca. Keuntungan yang diperoleh dari penjualan koran mulai diorganisasikan ke dalam perusahaan-perusahaan besar berskala nasional maupun internasional. Penciptaan nilai, pembagian rubrikasi berita, dan tabloidisasi dilakukan demi tercapainya keuntungan dari bisnis penerbitan tersebut. Hal yang sama juga dialami oleh pers ketika iklan-iklan mulai bermunculan. Habermas melihat ruang publik sudah tidak ada lagi batasannya dengan ruang privat ketika iklan-iklan ini muncul di dalam pers. Habermas konsisten terhadap pemisahan yang ia lakukan antara ruang publik dengan ruang privat. Baginya, ruang privat tidak boleh dicampuradukkan dengan ruang publik. Namun sayangnya hal tersebut kini sudah menjadi biasa, iklan-iklan yang muncul di dalam pers memperlihatkan bagaimana pertarungan-pertarungan kepentingan privat telah masuk ke dalam wilayah publik. Pers pun menjadi komoditas yang dapat diperjualbelikan. Kalau keadaannya sudah seperti ini, maka pers sebagai ruang publik kritis berubah menjadi panggung perdagangan dan panggung tontonan.

Dari permasalahan di atas, jurnalisme publik muncul sebagai jawab atas problem yang dihadapi pers sebagai ruang publik. Dalam pandangan Habermas, jurnalisme publik ini berupaya untuk mengembalikan fungsi pers sebagai ruang publik kritis sebagaimana yang dilakukan saat kemunculannya. Pers harus dibentuk sebagai media perjuangan, media penyampaian aspirasi, ekspresi, dan opini publik, serta harus menjadi pembela pada kepentingan emansipatoris. Kegiatan jurnalisme publik ini dapat dilakukan oleh jurnalis-jurnalis profesional, maupun oleh masyarakat secara amatir. Inti dari jurnalisme publik tersebut tidak lain untuk mendorong keterlibatan masyarakat di dalam partisipasi publik secara lebih luas.

Dari analisisnya mengenai ruang publik, Habermas membagi konsep ruang publik ke dalam dua jenis, yaitu ruang publik politik dan ruang publik sastra. Kedua konsep ruang publik tersebut memperlihatkan dua hal. Pertama, ruang publik menjadi ruang terbuka yang dapat diakses oleh semua orang. Publik juga tidak lagi dipahami sebagai status keningratan yang dipegang oleh penguasa (pemerintah). Setiap masyarakat memiliki hak yang sama untuk menyalurkan pendapat di dalam ruang publik. Pada saat yang sama, ruang publik ini juga memperlihatkan perubahan status masyarakat di mana setiap orang dari mana pun latar belakangnya mendapatkan hak yang sama di dalam ruang publik. Sebelumnya, kelas borjuis atau pengusaha yang hanya mendapatkan tempat di ruang publik, namun seiring perkembangan ruang publik, masyarakat biasa pun memiliki akses yang sama. Di sinilah ruang publik menjadi ruang inklusif di mana setiap orang diperlakukan setara.

Kedua, upaya masyarakat Eropa pada saat itu dalam menyalurkan aspirasi di ruang publik bergerak pada pengelolaan informasi. Kelompok-kelompok masyarakat membuat pamflet untuk menyalurkan aspirasi dengan menjalankan pengelolaan informasi secara sederhana. Lambat laun pengelolaan yang sederhana ini berkembang 
pada tahap yang lebih profesional. Pengelolaan informasi sudah mulai mengenal jadwal terbit, format media cetak juga mulai mengarah pada bentuk newsletter, dan rubrikasi dalam media juga sudah diterapkan.

Perkembangan pers yang terus meningkat mendorong pula pada persaingan bisnis diantara pengelola pers. Situasi ini memungkinkan pers berjalan sesuai kepentingan bisnis masing-masing pengelolaan. Kekhawatiran ini kemudian direspon dengan munculnya konsep jurnalisme publik, kegiatan jurnalisme yang tetap memperhatikan kepentingan-kepentingan publik. Setelah Habermas memberikan pandangan mengenai relasi ruang publik dan pers dalam karyanya The Structural Transformation of the Public Sphere, kajian mengenai ruang publik dan pers digunakan untuk merumuskan konsep jurnalisme publik oleh para peneliti seperti Jerremy Iggers (1999) dan Chris Atton (2002). Iggers memaknai jurnalisme publik ke dalam dua bentuk, yaitu jurnalisme publik sebagai kegiatan jurnalisme yang berkaitan dengan kepentingan-kepentingan publik, dan jurnalisme publik sebagai kegiatan bersama yang dijalankan oleh wartawan dengan masyarakat. Sedangkan Atton memaknai jurnalisme publik sebagai kegiatan dalam pengelolaan media alternatif, yang memiliki ciri-ciri sebagaimana yang telah peneliti paparkan pada bagian sebelumnya.

\section{Simpulan}

Berdasarkan hasil penelitian dan pembahasan yang telah dipaparkan, maka dapat disimpulkan bahwa istilah 'publik' pada awalnya memiliki pengertian keningratan yang memperlihatkan hak-hak keistimewaan yang dimiliki bangsawan. Pengertian publik ini berkembang, hingga ditemukan pandangan hukum Romawi yang dengan tegas mendefinisikan publik sebagai kepentingan umum (respublica). Habermas membagi ruang publik ke dalam dua jenis yaitu ruang publik politik dan ruang publik sastra. Keberadaan kedua jenis ruang publik ini memiliki makna dan ciri yang sama, yaitu ruang tersebut dapat diakses semua orang, adanya kesetaraan, status sosial dikesampingkan, tumbuhnya aktivitas kritis publik, dan berkembangnya ruang publik ke arah komodifikasi.

Perkembangan ruang publik sangat erat kaitannya dengan pertumbuhan literasi masyarakat dan munculnya kegiatan jurnalistik (pers) di Eropa. Kemunculan pers ditandai dengan dua hal, yaitu kebutuhan informasi yang berkaitan dengan kepentingan perdagangan atau komersial, dan kegiatan masyarakat di dalam ruang publik sastra yang telah banyak menghasilkan berbagai terbitan seperti jurnal, pamflet, newsletter, atau newsbook. Perkembangan ruang publik telah melahirkan kelas-kelas baru dalam masyarakat Eropa. Istilah borjuis pun meluas tidak hanya sebatas mereka yang bergerak di dunia bisnis perdagangan, melainkan kelas menengah yang datang dari berbagai profesi. Mereka inilah yang berkecimpung dalam ruang publik politik dan ruang publik sastra yang pada akhirnya menjadi embrio kemunculan pers.

Jurnalisme publik memiliki beragam bentuk diantaranya public journalism as journalisme about the public, yaitu jurnalisme publik yang berupaya untuk mendorong 
keterlibatan atau partisipasi masyarakat yang berkaitan dengan politik. Pers dalam hal ini mendorong, masyarakat agar dapat terlibat dalam segala urusan publik, sehingga segala keputusan atau kebijakan yang dikeluarkan oleh pemerintah dapat dilakukan melalui proses demokrasi deliberatif. Sementara itu bentuk public journalism as journalism with the public dimaknai sebagai bentuk jurnalisme publik yang menjadikan masyarakat sebagai mitra aktif, baik itu dalam proses pembuatan berita, maupun dalam rangka membangun kemampuan masyarakat untuk bekerjasama dalam menyelesaikan masalah-masalah atau dalam rangka mencapai target-target yang masyarakat inginkan.

Bagi peneliti yang tertarik untuk melakukan penelitian mengenai jurnalisme publik, dapat melakukan penelitian lapangan berkaitan dengan perkembangan jurnalisme publik atau bentuk-bentuk baru jurnalisme publik terutama pada perkembangan media teknologi digital saat ini. Penelitian lapangan juga bisa dilakukan dengan mengkaji peran jurnalisme publik saat ini dalam meningkatkan partisipasi masyarakat di Indonesia.

\section{Daftar Pustaka}

Atton, C. (2002). Alternative Media, London: Sage Publications Ltd.

Bakker, Anton dan Zubair, Achmad Charris, (1990), Metodologi Penelitian Filsafat, Kanisius, Yogyakarta.

Berry, D. (2008). Journalism, Ethics and Society. England: Ashgate Publishing Limited.

Dowd, D. (2000). Capitalism and its Economics: A Critical History. London: Pluto Press.

Cangara, Hafied, 1998, Pengantar Ilmu Komunikasi, Rajawali Press, Jakarta.

Eaman, R. (2009). Historical Dictionary of Journalism, Maryland: Scarecrow Press. Inc.

Fulcher, J. (2004). Capitalism; Very Short Introduction. New York: Oxford University Press Inc

Habermas, J. (1989). The Structural Transformation of the Public Sphere. (trans) Thomas Burger, Britain: Polity Press.

Hardiman, F.B. (2009). Menuju Masyarakat Komunikatif: ilmu, Masyarakat, Politik dan Postmordenisme Menurut Jurgen Habermas. Yogyakarta: Kanisius.

. (2009). Demokrasi Deliberatif: Menimbang 'Negara Hukum' dan 'Ruang Publik' dalam Teori Diskursus Jurgen Habermas, Yogyakarta: Kanisius.

Haryatmoko. (2007). Etika Komunikasi; Manipulasi Media, kekerasan, dan pornografi, Yogyakarta: Kanisius. . (2003), Etika Politik dan Kekuasaan, Kompas, Jakarta

Iggers, J. (1999). God New Bad News: Journalism Ethics and the Public Interest. Colorado: Westview Press. 
Jones, P. (2009). Pengantar Teori-Teori Sosial. (terj). Achmad Fedyani Saifuddin, Jakarta: Yayasan Obor Indonesia.

Kaelan. (2013), Metode Penelitian Kualitatif Interdisipliner Bidang Sosial, Budaya, Filsafat, Seni, Agama dan Humaniora, Paradigma, Yogyakarta.

Junaedhi, Kurniawan, (1991), Ensiklopedi Pers Indonesia, Gramedia, Jakarta.

McQuail, D. (1997). Audience Analysis. London; Sage Publication.

Mwangi, S.M. (2009). International Journalism in 21st Century Communication a Reference Handbook (ed) William F. Eadie. California: Sage Publications, Inc.

Rundel, J. (2005). Jurgen Habermas, dalam Teori-Teori Sosial; Observasi Kritis terhadap Para Filsuf Terkemuka (ed) Peter Beilharz, Yogyakarta: Pustaka Pelajar.

Schmandt, H.J. (2002). Filsafat Politik: Kajian Historis dari Zaman Yunani Kuno Sampai Zaman Modern, (terj) Ahmad Baidlowi \& Imam Bahehaqi, Yogyakarta: Pustaka Pelajar.

Santana, K.S. (2005). Jurnalisme Kontemporer, Jakarta: Yayasan Obor Indonesia.

Siswanto, J. (1998). Sistem-Sistem Metafisika Barat. Yogyakarta: Pustaka Pelajar.

Stell, J. (2009). The Idea of Journalism. in 21st Century Communication a Reference Handbook (ed) William F. Eadie. California: Sage Publications, Inc.

Sunarjo, Djoenarsih S, 1991, Pengantar Ilmu Komunikasi, Pembangunan, Jakarta.

Turow, J. (2009). Media Today: An Introduction to Mass Communication. New York: Routledge.

Wellmer, A. (1991). Reason, Utopia, and the Dialectic of Enlightenment, dalam Habermas and Modernity, Richard J. Bernstein. Cambridge-Massachusetts: The MIT Press.

Wiryawan, H. (2007). Dasar-Dasar Hukum Media, Yogyakarta: Pustaka Pelajar. 